\title{
Study of Iranian English language teachers' familiarity with language functions in request, apology, refusal, and greeting
}

\author{
Valipour, Sanaz $\bigotimes$ \\ Azad University of Maragheh, Iran (valipoursanaz@yahoo.com) \\ Jadidi, Saleh \\ Peyamnour University of Ajabshir, Iran (saleh_jadidi@yahoo.com)
}

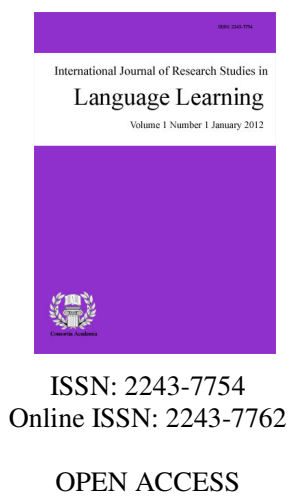

Received: 2 February 2014

Revised: 16 March 2014

Available Online: 20 March 2014

DOI: $10.5861 /$ ijrsll.2014.712

Accepted: 18 March 2014

\section{Abstract}

One of the major aims in the modern teaching of foreign language is to enable the learners to communicate appropriately in target language. Pragmatic competence is a need for everyone to communicate appropriately. Speech acts are one of the most important elements of pragmatic competence. In this respect, the main aim of this study was to investigate Iranian English language teachers' familiarity with language functions in four of basic and important face threatening speech acts: Request, Refusal, apology, Greeting. The participants involved 30 English language teachers that comprised of 15 males and 15 females. A Written Discourse Completion Test (DCT) and multiple choice discourse completion questionnaires (MDCT) were used to generate participant's data. Selection of situations in WDCT was based on three social factors of relative power, social distance, and gender. The emerging data was analyzed mainly based on Blum-Kulka et al.'s Cross-cultural Speech Act Realization Project (CCSARP) and by using descriptive statistics. The data analysis revealed that the participants had enough knowledge about speech act and politeness strategies. In requesting, they mainly relied on indirect strategies; similarly, in refusing, they had a tendency towards using indirect strategies more than direct ones; in apologizing they acted more directly and in greeting they used verbal behaviors and hello expression more than hi expression and non-verbal behavior in formal situations. Based on Brown \& Levinson's politeness theory, Iranian EFL Teachers in this study mainly resorted to negative politeness strategies.

Keywords: politeness strategy; communicative competence; request; refusal; apology; greeting 


\section{Study of Iranian English language teachers' familiarity with language functions in request, apology, refusal, and greeting}

\section{Introduction}

To be able to use the target language effectively, language learners should develop target language communicative competence. One of the main components of the communicative competence is pragmatic competence. Foreign language teachers in order to be able successfully to perform speech acts; they should use functions of language contextually in communicative oral activities in different situations in order to develop their ability in use of target language. Therefore, people use different functions differently in particular contexts and these functions play a major role in communication and interaction .The way participants decide which form or function to use in particular context depends on some factors such as the social distance between the participants ,their relative status, and the formality of context. Because these functions are very important in maintaining and developing relationship, speech acts like greeting, requesting and apology and refusing have been chosen in the present study. If one can't apply pragmatic competence appropriately, misunderstanding can arise despite having a wide range of vocabulary and a sound knowledge of grammar. Wierzbicka (1991) defines politeness, as a person's effort to respect other's right, autonomy and privacy. At the center of all politeness models is the notion of indirectness. This notion is of high importance in speech acts, because it determines to what extent communication may end in failure or success. The communicative function of an utterance corresponds to the speaker's intention in producing a given message (Alemi \& Irandoost, 2012).

Request, refusal, apology, and greeting are important areas of research in second and foreign languages, So many investigations have been done Cross-cultural, Interlanguage, and with different participants. These mentioned speech acts never have been done about Iranian English language teachers; Therefore, the current study analyzes Iranian English language teachers' familiarity with language functions in refusals, apologizes, greetings, and requests from appropriately communicating ( politeness) view point. It attempts to investigate Iranian ethos in different speech acts and find out the effect of gender as cultural and moderator variable on requesting, apologizing, refusing, and greeting strategies. It also studies what extent teachers are aware of them. By focusing on these functions, we want to provide some contributions to the act of communication and recognize the evaluation of a passage requires knowledge of functions relevant to the situational context. It is intended to explain how politeness operates in conversational exchanges and for this reason politeness strategies are very important in communicating target language. So this thesis can be helpful for the students and more teachers as a foreign language teacher in English classrooms. It also states that teachers should possess additional information about using the pragmatic knowledge in particular situational context in spite of having grammatical and vocabulary knowledge. This also helps to improve communicative competence more than grammatical competence.

Following this tradition of research in general and to gain a deeper understanding of Iranian English language teachers' familiarity with language functions, the present research attempted to investigate a group of Iranian teachers' familiarity with language functions in four speech acts (Request, Refusal, Apology, and greeting). The study attempted to investigate Iranian ethos in using and understanding different speech acts. We also studied the types of head acts, supportive discourse moves, on- record, and off- record strategies employed by participants in their speech acts in different contexts. More specifically, the present research addressed the following questions: 1-Do Iranian English language teachers in BA level have enough knowledge in functions of language, speech acts and politeness strategies? For answering this question, some sub-questions should be answered? a) Are they familiar with requesting strategies and what are the request strategies used by them? b) Are they familiar with apologizing and what are the apology strategies used by them? c) Are they familiar with refusal strategies and what are the refusal strategies used by them? d) Are they familiar with greeting strategies and 
Iranian English language teachers' familiarity with language functions in request, apology, refusal, and greeting what are the greeting strategies used by them? 2-Do they have a tendency towards one of the five main politeness strategies, toward which one or ones?

\section{Review of the Related Literature}

\subsection{Politeness}

Politeness involves taking account of the feelings of others. A polite person makes others feel comfortable. Goffman (1967) was concerned with social interaction that refers to behavior that was used by individuals in social interaction. Goffman developed the concept of face and later "face-work" in 1967 in order to explain how people interact and maintain each other's face. Participants avoid face-threatening acts in order to protect and save face of self and others. In conversation both parties have duty to maintain face. Goffman posited ideas of two faces: Negative face and Positive face. In negative face, the speaker is free and independent from society. The speaker doesn't follow the rules of politeness and he doesn't maintain his face in the society. In positive face, the speaker wants to be accepted in society by following the rules of politeness (Stapleton, 2004).

Brown and Levinson (1987) outline five main types of politeness strategies based on the minimization of loss of face by face-threatening acts (FTA). Their face saving strategies (numbered 1-5) can be observed in the following chart in figure 1 .

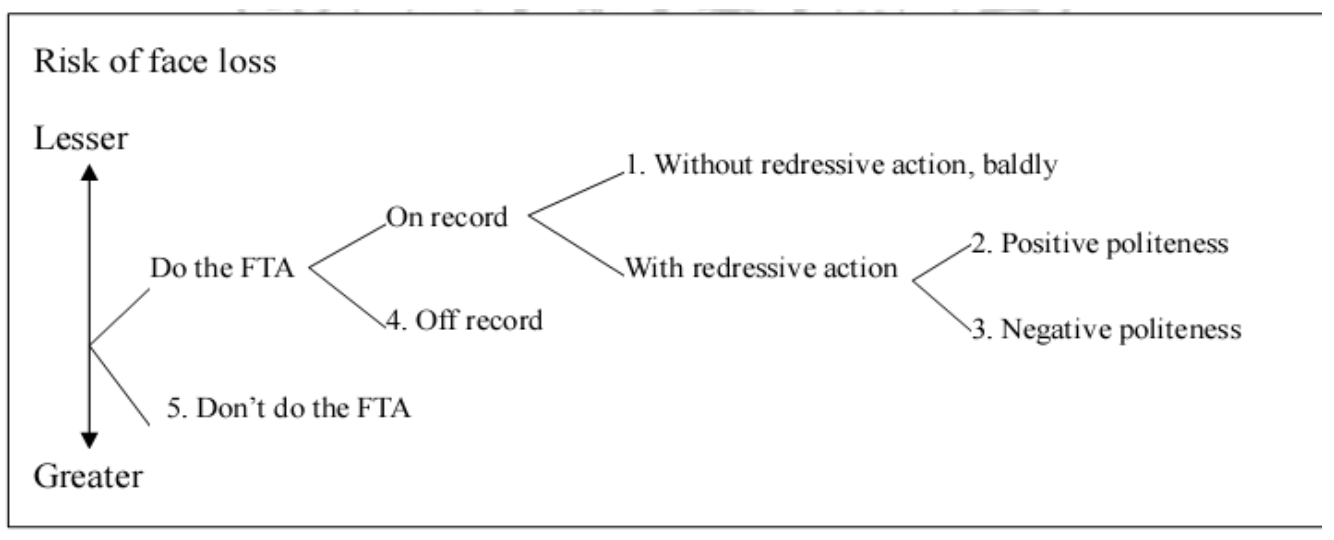

Figure 1. Possible strategies for doing face-threatening acts. Source: (Brown \& Levinson, 1987, p. 69)

\subsection{Speech Acts Investigated in the Present Research}

Austin (1962) claims that many utterances (things people say) are equivalent to actions. People use language all the time to make things happen. According to speech act theory (Austin, 1962; Searle ,1969), the performance of a speech act involves the performance of three types of acts: locutionary act (what we say), illocutionary act, (what we mean), and perlocutionary act (how the hearer takes it). Searle (1975) distinguished 'direct' and 'indirect' speech acts. A direct speech act carries the illocutionary force indicating devices (IFID), in which there is a transparent relationship between form and function. However, in an indirect speech act, the illocutionary force of the act is not derivable from the surface structure and it is implicit performative. Of the many types of speech acts included in the proposed taxonomies, here we suffice with defining the ones which have been investigated in the present research and highlighting their role in establishing politeness.

Request - According to Byon (2004, p. 1674), Request is a directive speech act that speaker attempts to get the hearer to do something for a speaker's goal. According to Searle's (1976) classification of illocutionary acts, researchers let requests fall under the second category, that of directives, which have been regarded as: "attempt by the speaker to get the hearer to do something" (Reiter, 2000, p. 35). Blum-Kulka (1991, p. 257) described requests as being "pre-event" acts that intend to affect the hearer's behavior and speakers strive to achieve requestive 
goals with maximum effectiveness and politeness that these goals are the motivational, intentional source of a request (Al-Momani, 2009). Blum-Kulka, House, and Kasper (1989) cited in Jalilifar (2009) classify requests into three major levels of directness: direct (Mood derivable, Performative, Hedged performative, Obligation statement, Want statements), conventionally indirect (Suggestory formula, Query preparatories) and non-conventionally indirect (Strong hint, and Mild hint).

Refusal - Refusals are considered face-threatening acts among the speech acts. A refusal is a response "no" to an offer, request, invitation, etc. Sending and receiving a message of "No" requires to special skill. Beebe et al. (1990) cited in Phuong (2006) classified refusal strategies as: direct (Performative, Non-performative statement (NO), Non-performative Negative willingness ability), indirect (Statement of regret, Statement of wish, Excuse/reason/explanation, Statement of alternative, Set condition for future or past acceptance, Promise of future acceptance, Statement of principle, Rhetorical question, Threat/statement of negative consequences, Restatement, Unwillingness/insistence, Postponement), and Adjuncts to Refusals (Statement of positive opinion/feeling or agreement, Statement of empathy, Addressing terms).

Apology - Searl (1976) states that apologies are face threatening acts and he classifies it as expressive act. Olshtain and Cohen (1983) state that this classification is not a good way for explaining exactly what a speech act is (Gonda, 2001). According to Brown and Levinson (1987), apologies are negative politeness strategies because they are face threatening to the apologizer"(Alfattah, 2010). Olshtain and Cohen (1983) as cited in Gonda (2001) studied apologizing strategies and classified them into Illocutionary force indicating device (taking on responsibility, explanation or account, offer of repair, and promise of forbearance) and Tunçel added categories like questioning or denying, blame, health, exclamation, and request to the list.

Greeting - According to the New Lexicon Webster's Dictionary, greet is to address with Courteous words" or "gesture on meeting". Greeting is defined as an expression or Gesture used when meeting someone", or "a form of address at the beginning of a letter" e. g. dear sir (as cited in Jibreen, 2010). Halliday (1979) has classified greeting into time-free and time-bound greeting. According to Krivonos and Knapp (1975), time-free and time-bound constitute two new forms of the verbal greetings and they also state that two types of greetings are involved: Verbal and non-verbal. Halliday's (1979) classification of time-bound greetings implies additional terms to refer to different uses of time-bound greetings. These are formal vs. informal ones.

\section{Methodology}

The purpose of the researcher is to assess the pragmatic knowledge of Iranian EFL teachers in relation to the speech acts of request, apology, refusal, and greeting in EFL classrooms and to investigate knowledge levels of various forms of requests, refusals, apologies and greetings as produced by Iranian English language teachers in Azerbaijan, Iran. Since they had passed several courses in grammar, reading, conversation and writing up to advanced level in university; it was assumed they had enough proficiency in written production.

\subsection{Participants and Instruments}

The participants in this study were 30 English teachers (15 females and 15 males) from high schools and institutes in Ajabshir and Maragheh, Iran. The participants were chosen BA with similar level of language proficiency according to stratified random sampling. Almost all of them were between 22 and 45 years of age. Two tests were two parts in this investigation: Multi-choice discourse completion test (MDCT), and written discourse completion test (WDCT). Despite the limitations of MDCT, it analyzes teachers' performance. MDCTs analyze participants' performance by testing speech act and pragmatic knowledge. It was included three alternatives to be chosen by participants. The (WDCT) is a form of questionnaire depicting some natural situations to which the respondents are expected to react and make speech acts as spontaneous as possible. WDCT had four parts in this study: Each part involves twelve written dialogues that denote forty-eight different situations. The situations vary according to a number of social variables: in terms of social status or power with 

three levels: High (h), equal (E), and L (low); social distance with two levels: intimate (I) and stranger(S); and gender relationship with two levels: same(S) and opposite $(\mathrm{O})$ (see appendix A and B).

\subsection{Procedure of data analysis}

The data was gathered through MDCT and WDCT questionnaire among Iranian English language teachers. The purpose was to investigate female and male Iranian English language teachers' familiarity with language functions in request, refusal, apology, and greeting. In order to test the hypotheses of the study, Blum-Kulka, et al.'s Coding Manual which was designed as a result of the Cross-cultural Speech Act Realization Project (CCSARP) was used as the main data analysis framework. Brown and Levinson's politeness theory (1987) was also taken for comparing data. Finally, the results mainly were analyzed qualitatively; however, quantitative analysis was also used in analyzing of questionnaires by using statistical analysis (Excel). Blum-kulka et al. (1989) CCSARP in analyzing request strategy, Beeb et al. (1990) and Phoung (2006) in analyzing refusal strategy, Blum-kulka et al,'s (1989) CCSARP in analyzing apology strategy and Halliday's categorization, Krinovos and knap (1975) were used in analyzing greeting strategy. Three categories depicted the relative social power - high (H), equal (E), lower (L); social distance with two levels: intimate (I) or stranger (S); and gender: Same $(\mathrm{S})$ or Opposite $(\mathrm{O})$ - were used.

\section{Result}

\subsection{Analysis of first part of questionnaire}

Apology strategies (MDCT) - The results obtained from the first questionnaire (MDCTs) are presented in Table 1. It displays the percentage and frequency of apology responses that the participants chose in each situation. It compares the apology strategies used by two groups:

\section{Table 1}

Most frequent 5 strategies used to apologize

\begin{tabular}{|c|c|c|c|c|}
\hline \multirow{2}{*}{ Strategies } & \multicolumn{2}{|c|}{ Frequency } & \multicolumn{2}{|c|}{ Percent } \\
\hline & $(\mathrm{F})$ & (M) & $(\mathrm{F})$ & (M) \\
\hline $\begin{array}{l}\text { Situation 1:IFID+ promise of forbearance+ an acknowledgement of } \\
\text { responsibility }\end{array}$ & 8 & 9 & $53.33 \%$ & $60 \%$ \\
\hline $\begin{array}{l}\text { Situation } 2 \text { :IFID }+ \text { an explanation or account }+ \text { an acknowledgement of } \\
\text { responsibility+ an offer of repair }\end{array}$ & 11 & 9 & $73.33 \%$ & $60 \%$ \\
\hline $\begin{array}{l}\text { Situation 3:IFID+ an acknowledgement of responsibility }+ \text { promise for } \\
\text { forbearance }\end{array}$ & 8 & 9 & $53.33 \%$ & $60 \%$ \\
\hline Situation 4:IFID+ an explanation or account & 13 & 12 & $86.66 \% *$ & $80 \%$ \\
\hline $\begin{array}{l}\text { Situation5: IFID+ An acknowledgement of responsibility+ Promise for } \\
\text { forbearance }\end{array}$ & 8 & 8 & $53.33 \%$ & $53.33 \%$ \\
\hline
\end{tabular}

Table 1 shows that an expression of an apology (IFID) is the first formulae in the list of apologies strategies. It is the most direct realization of an apology. Table 1 demonstrates that the subjects possess the basic IFID formulae accompanying with one or two other strategies.

Request strategies (MDCT) - The results obtained from the first questionnaire (MDCTs) are presented in Table 2. It displays frequency and percentage of the request strategies responses that the participants chose in each situation. It compares the request strategies used by two groups.

Table 2 shows that an expression of alerter strategy is the first formula in the list of request strategies with head act strategies. It demonstrates that the subjects possess the basic alerter strategy accompanying with one or two other head act strategies. 
Valipour, S. \& Jadidi, S.

Table 2

Most Frequent 5 Strategies Used to Request between Female and Male Teachers

\begin{tabular}{|c|c|c|c|c|}
\hline \multirow{2}{*}{ Strategies } & \multicolumn{2}{|c|}{ Frequency } & \multicolumn{2}{|c|}{ Percent } \\
\hline & $(\mathrm{F})$ & $(\mathrm{M})$ & $(\mathrm{F})$ & $(\mathrm{M})$ \\
\hline Situation 1:Alerter + hedge performative & 13 & 11 & $86.66 \% *$ & $73.33 \%$ \\
\hline Situation 2 :Alerter + strong hints & 13 & 11 & $86.66 \% *$ & $73.33 \%$ \\
\hline Situation 3:Alerter + strong hints+ Mild hints & 12 & 9 & $80 \%$ & $60 \%$ \\
\hline Situation 4 :Strong hints & 13 & 13 & $86.66 \% *$ & $86.66 \%$ \\
\hline Situation 5: Strong hints + suggestory formula & 10 & 12 & $66.66 \%$ & $80 \%$ \\
\hline
\end{tabular}

Refusal strategies - The results obtained from the first questionnaire and included refusal strategies are presented in table 3. It displays the percentage and frequency of the refusal strategies responses that the participants chose in each situation. It displays the percentage and frequency of the refusal strategies responses that the participants chose in each situation.

\section{Table 3}

Most Frequent 5 Strategies Used to Refuse Between Two Groups

\begin{tabular}{lllll}
\hline \multirow{2}{*}{ Strategies } & \multicolumn{2}{c}{ Frequency } & \multicolumn{2}{c}{ Percent } \\
\cline { 2 - 5 } & $(\mathrm{F})$ & $(\mathrm{M})$ & $(\mathrm{F})$ & $(\mathrm{M})$ \\
\hline Situation 1: statement of regret + negative willingness ability & 9 & 8 & $60 \%$ & $53.33 \%$ \\
Situation 2 : Statement of regret+ reason & 10 & 14 & $66.66 \%$ & $93.33 \% *$ \\
Situation 3: statement of regret+ reason+ explanation & 11 & 9 & 73.33 & $60 \%$ \\
Situation 4: addressing terms+ statement of regret+ Reason+ explanation & 9 & 9 & $60 \%$ & $60 \%$ \\
Situation 5: statement of positive opinion/feeling or agreement+ & 13 & 7 & $86.66 \% *$ & $46.66 \%$ \\
statement of regret & & & &
\end{tabular}
statement of regret

Note: Letters in parentheses indicate the gender of participants who completed the test, $\mathrm{F}=$ female, $\mathrm{M}=$ male Maximum percentage: situation 2, 5= M $>\mathrm{F}, \mathrm{F}>\mathrm{M}$

Table 3 shows that a statement of regret is the first formula in the list of refusal strategies. It demonstrates that the subjects possess the basic statement of regret accompanying with reason or explanation

Greeting strategies - The results obtained from the first part of the questionnaire and included greeting strategies are presented in table 4. It displays the percentage of the greeting strategies responses that the participants chose in each situation.

\section{Table 4}

Most Frequent 5 Strategies Used to Greet by participants

\begin{tabular}{|c|c|c|c|c|}
\hline \multirow{2}{*}{ Strategies } & \multicolumn{2}{|c|}{ Frequency } & \multicolumn{2}{|c|}{ Percent } \\
\hline & $(\mathrm{F})$ & $(\mathrm{M})$ & $(\mathrm{F})$ & $(\mathrm{M})$ \\
\hline Situation 1: statement of regret + negative willingness ability & 9 & 8 & $60 \%$ & $53.33 \%$ \\
\hline Situation $2:$ Statement of regret+ reason & 10 & 14 & $66.66 \%$ & $93.33 \%$ \\
\hline Situation 3: statement of regret+ reason+ explanation & 11 & 9 & 73.33 & $60 \%$ \\
\hline $\begin{array}{l}\text { Situation 4: addressing terms+ statement of regret+ Reason+ } \\
\text { explanation }\end{array}$ & 9 & 9 & $60 \%$ & $60 \%$ \\
\hline $\begin{array}{l}\text { Situation 5: statement of positive opinion/feeling or agreement+ } \\
\text { statement of regret }\end{array}$ & 13 & 7 & $86.66 * \%$ & $46.66 \%$ \\
\hline
\end{tabular}

The results in table 4 show that the most use of greeting strategies in these situations are formal expressions such as hello plus addressing terms and time-free greetings. Table 4 shows that hello expression and time-free greetings are the first formulas in the list of greeting strategies. Table 4 demonstrates that the subjects possess the basic statement of Hello or addressing terms accompanying time-free or time-bound greeting. 


\subsection{Analyzing second questionnaire (WDCT)}

Figure 2 displays the comparison of requesting head act strategies used between male and female participants. It shows that both groups used nearly the same strategies in their communication.

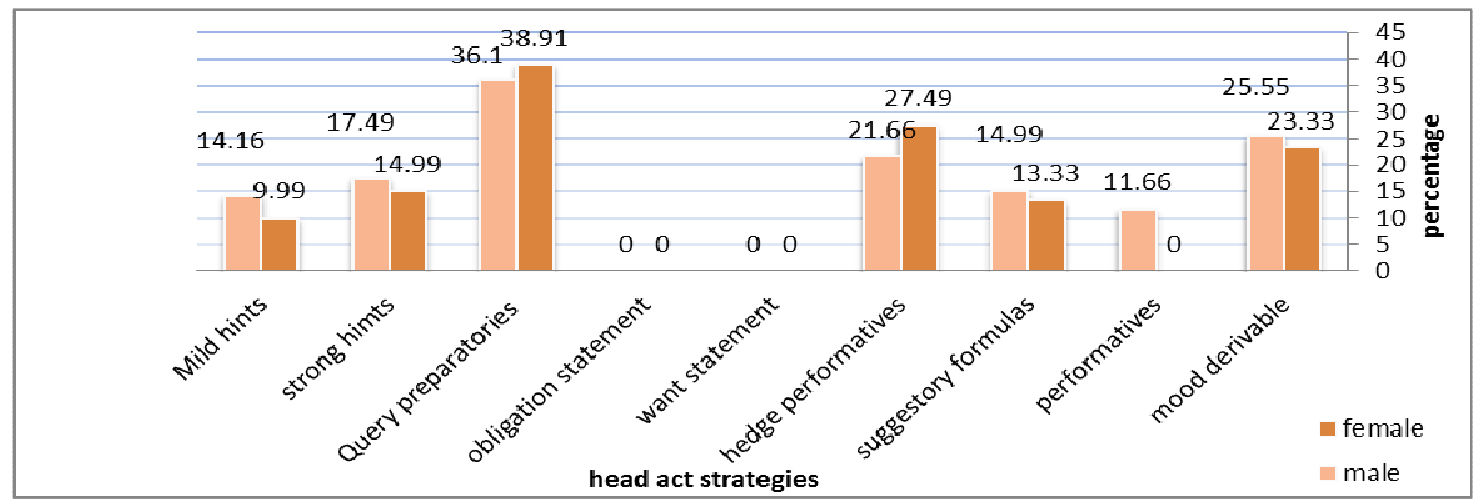

Figure 2. Comparison of requesting head act strategies used by male and female participants

Generally speaking, the participants in this study used the indirect strategy the most, corresponding to a percentage of $15.51 \%$. The second and third used strategy observed in the participant's data are direct strategy and non-conventionally indirect strategy corresponding to a percentage of $15.13 \%$ and $14.15 \%$ (see figure 3 ). This finding shows that participants in this study used high level of politeness strategies.

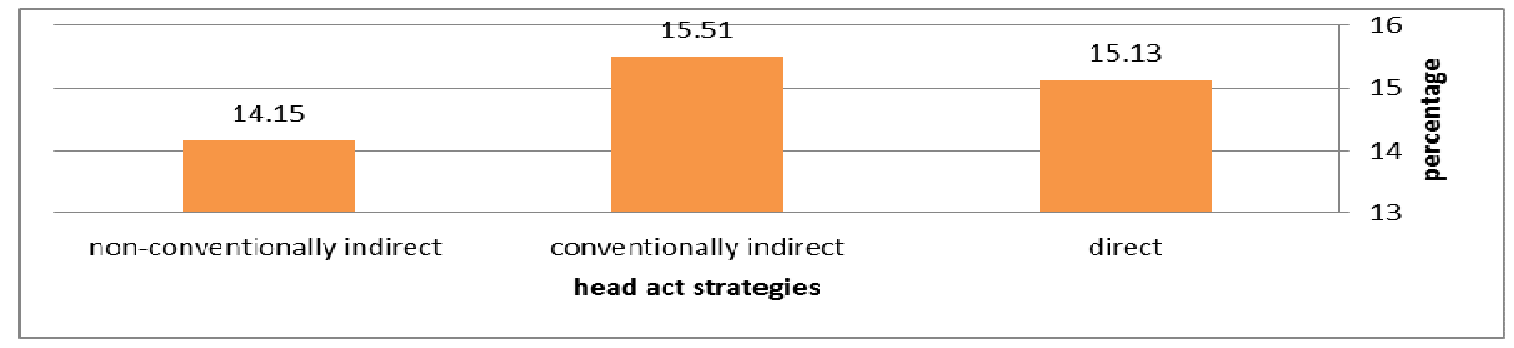

Figure 3. Distribution of requesting head act strategies based on directness

Figure 4 compares the Requesting Mitigating Supportive Moves used by both groups. It clearly shows that male respondents' performance closely corresponds with the performance of female participants. But, females preferred to use all of the mitigating supportive moves more than males did. It is likely due to the gender differences: female participants appear to be more sensitive than males in saving addressee's face. The grounder mitigating supportive move was found to have the highest frequency level with percentage of $21.10 \%$ in female groups.

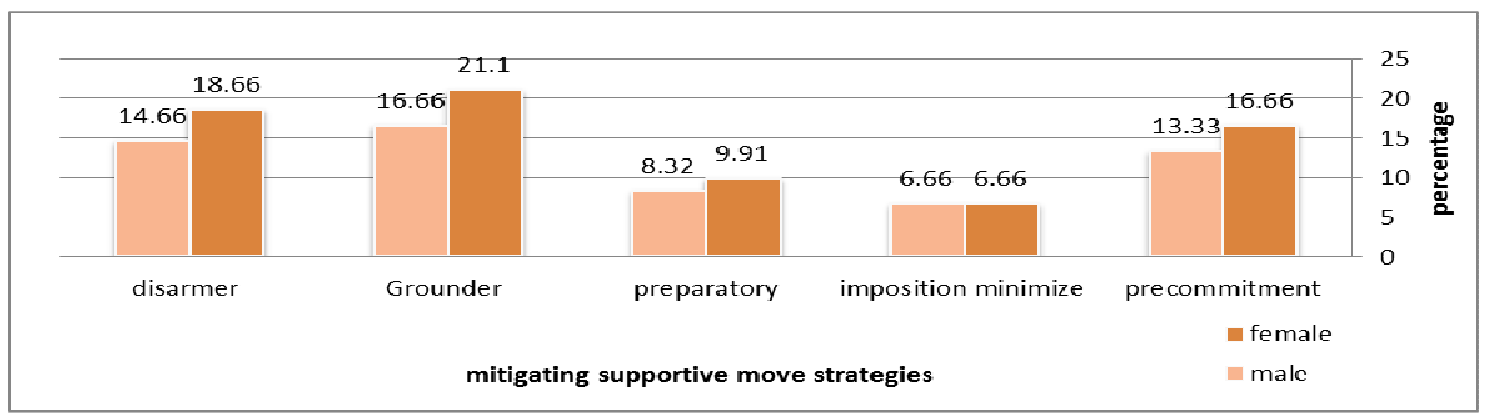

Figure 4. Comparison requesting mitigating supportive moves used by male and female Participants

The grounder mitigating supportive move was found to have the highest frequency level with percentage of $21.10 \%$ in the female group. Figure 5 shows the comparison between two groups in use of refusal strategies. It is 
Valipour, S. \& Jadidi, S.

clear that there are not lots of differences between them and they interacted in the same way. Only it was in situation IIIA that female participants had a different performance ( $11.6 \%$ for females vs. $6.66 \%$ for males). Generally speaking, the participants in this study have preferred to use indirect strategies like Excuse/Reason/Explanation (IIC) and Statement of regret (IIA) more frequently (20.29\% and 16.38\%).

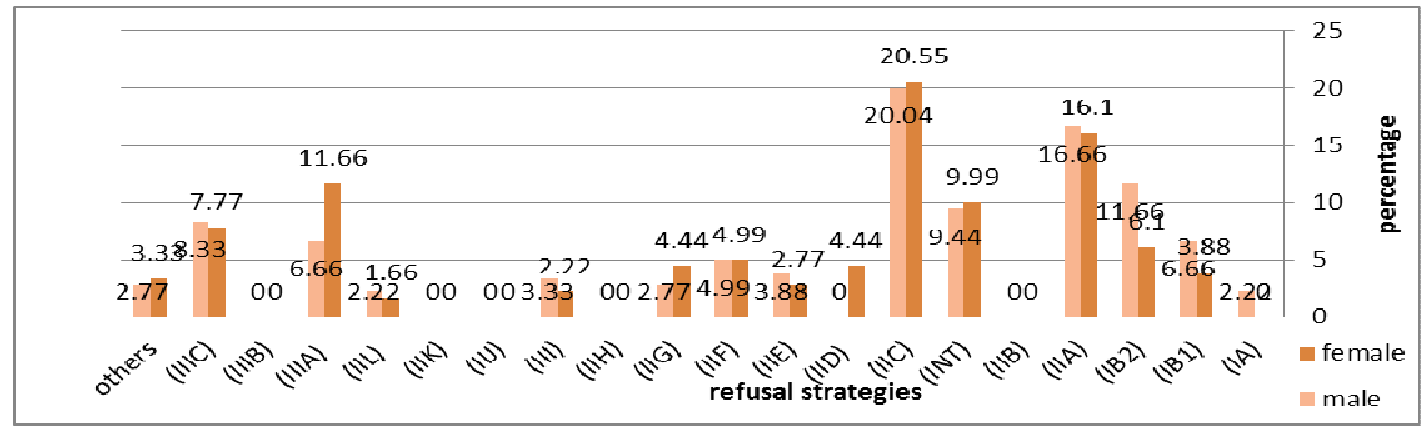

Figure 5. Comparison of refusal strategies used by male and female participants

According to Figure 6, all the participants used Illocutionary force indicating device (IFIDS) strategy the most with percentage of $21.1 \%$. The second most commonly used apologizing strategy by the participants was exclamation and intensifying corresponding to a percentage of $16.66 \%$. The third strategy was offer of repair/ redress (REPR) with percentage of $15.27 \%$ and the speaker will compensate the addressee for any damage resulting from his/her infraction. The fourth most commonly used strategy used by them was acknowledging responsibility for the offence (RESP) corresponding to a percentage of $14.99 \%$. The next strategy used by them was explanation of account (EXPL) with percentage of $13.05 \%$. The speaker gives an account of the reasons which brought about the offense (see figure 6).

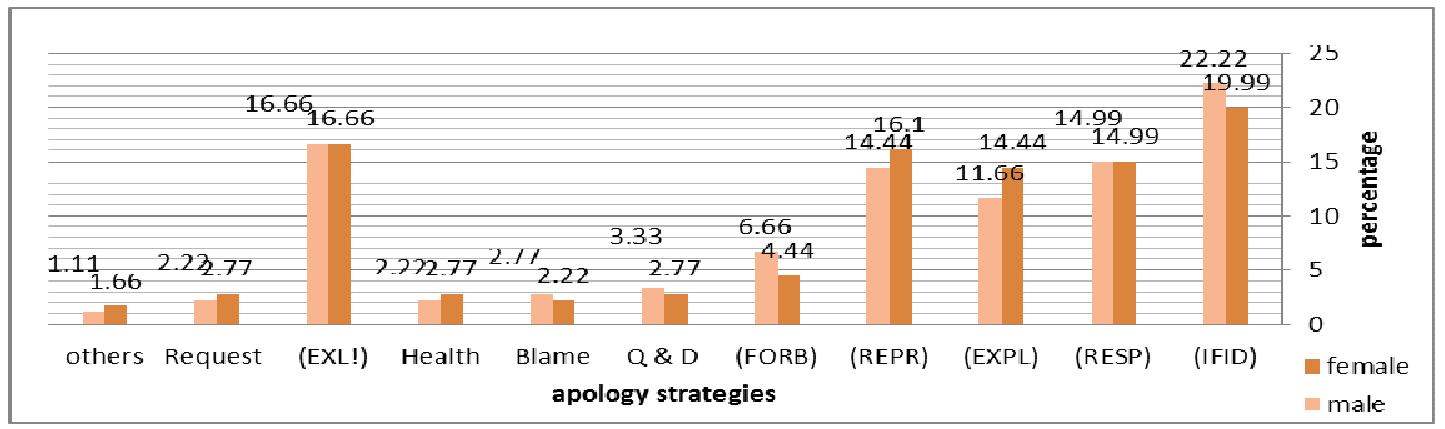

Figure 6. Comparison of apologizing strategies used by male and female participants

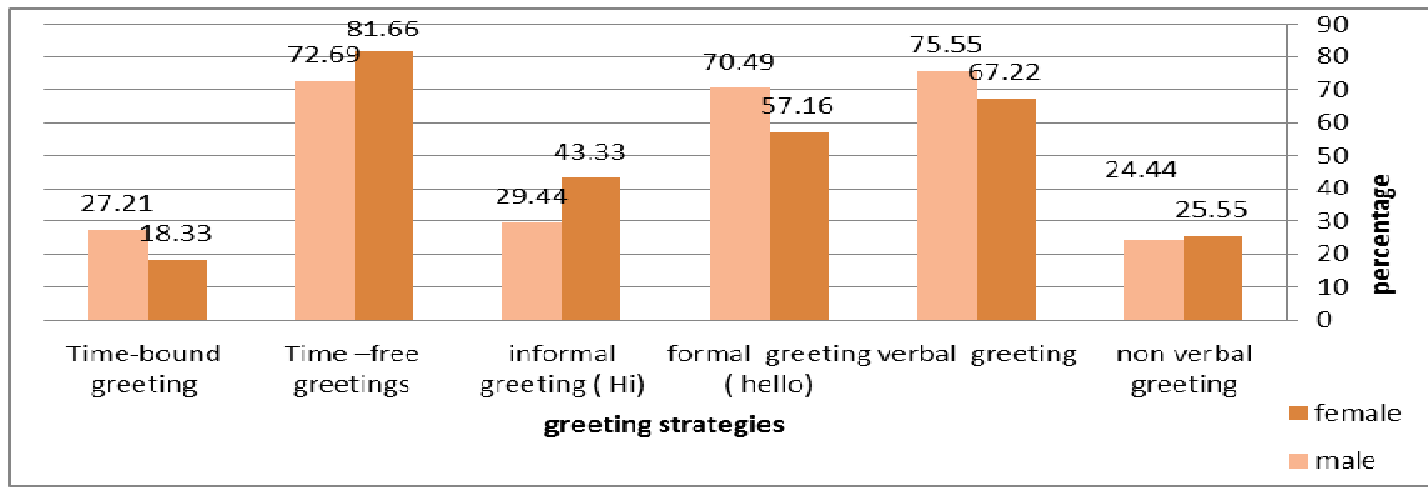

Figure 7. Comparison of greeting strategies used by male and female participants

According to figure 1, the first most strategy used by all participants was verbal greeting with a percentage of $71.38 \%$ and non-verbal greeting with a percentage of $24.99 \%$. Verbal greeting includes time-free and time-bound greeting in greeting strategy. The participants used time-free greeting more than time-bound greeting 

with percentage of $77.17 \%$. They also used Hello (formal) expression with percentage of $63.82 \%$ and $\mathrm{Hi}$ expression (informal) with $36.38 \%$.

\section{Discussion}

Research question 1: Do Iranian English language teachers in BA level have enough knowledge in functions of language, speech act and politeness strategies?

The results obtained from the first part of questionnaire shows clearly that participants had enough cognitive knowledge about functions of language, speech acts and politeness. The results of the analysis of requesting, indirectness strategies in Refusing, directness with intensifying and mitigating in apologizing, verbal behaviors in the most situations, and hello in formal situations in greeting. They also used non- verbal less than verbal in informal situations.

Research question 1a: Are they familiar with requesting strategies and what are the request strategies used by them?

The participants are familiar with request strategies. According to figure 2, the most commonly used head act strategy by the both groups is the query preparatory head act strategy corresponding to $37.50 \%$. This strategy is within conventional indirectness of requesting head act strategy and both groups employed indirectness corresponding to a percentage of $15.51 \%$. The results of the study revealed that Grounder strategy corresponding to a percentage of $18.18 \%$ was found the most mitigating supportive moves strategies used among participants. The participants used to give reasons, explanations, or justifications for her/ his request in most situations to minimize the negative effect of their request. From Brown and Levinson's (1978) politeness theory perspective, participants used negative politeness strategies in this finding. Since requesting speech act is a face threatening act, participants used Query preparatory as a conventional indirectness, Grounder, and please as mitigating supportive moves to minimize the negative effect of their request on the hearer.

Research question $1 b$ : Are they familiar with apologizing strategies and what are the apology strategies used by them?

Table 1 show that an expression of an apology (IFID) is the first formulae in the list of apologies strategies. It is the most direct realization of an apology. Table 1 demonstrates that the subjects possess the basic IFID formulae accompanying with one or two other strategies. The results of the apologizing strategies in figure 6 also shows that the participants used Illocutionary force indicating device (IFID) with percentage of $21.10 \%$ and it is the first commonly used apology strategy among them. The findings show that teachers used intensifying \& exclamation with direct expression of apology with the percentage of $16.66 \%$ in the majority of situations. This study comes in line with Reiter (2000).

Research question 1c: Are they familiar with refusal strategies and what are the refusal strategies used by them?

The findings of the refusal strategy in this study show that the respondents mostly have preferred to use excuse/Reason/ Explanation (IIC) corresponding to a percentage of $20.29 \%$. The second mostly used strategy by the participants was statement of regret (IIA)with percentage of $16.38 \%$. The participants used indirect strategies more than direct ones and more than average of the thirteen other strategies. It shows that they are familiar with refusal strategies and more polite persons by using of indirectness in their respondents.

Research question 1d: Are they familiar with greeting strategies and what are the greeting strategies used by them?

According to table 1 and figure 7, Hello expression is the first formulas plus time-free greetings in the most situations. The participants are familiar with greeting strategies and they use greeting strategies formally most of the time. Verbal greetings were used by them in some formal situations and non-verbal greetings less than verbal 
in informal situations. The participants used hello as formal expression and addressing terms such as Mr. and Mrs. in most of the situations.

Research question 2: Do they have a tendency towards one of the five main politeness strategies, toward which one or ones?

According to Brown and Levinson's (1987) politeness theory, participants in this study regarded interlocutor's negative face; therefore, they preferred to use negative politeness strategies. Since these mentioned are faces threatening acts by nature, the participants used mitigating supportive moves, softeners, and intensifiers to minimize the negative effect of their requesting, refusing, apologizing, and greeting. The result of this part doesn't confirm the hypothesis number two; it is clear that the Iranian English language teachers have tendency towards negative politeness strategies. According to figure 2, there were no major differences between these two groups regarding their overall requesting strategies. However, male participants used performative, mood derivable, suggestory formulas, strong hint, and mild hints head act strategies more frequently than did females. In contrast, the females used Query preparatories, Hedge performative frequently than did the males. A tentative interpretation might be that females have a stronger tendency towards using conventionally indirect strategy. To use Brown \& Levinson's (1987) politeness terminology, it is an off record strategy by which speakers use indirect language and remove the potential imposing on the hearer. Figure 4 compares the Requesting Mitigating Supportive Moves used by both groups. It clearly shows that male respondents' performance closely corresponds with the performance of female participants. But, females preferred to use all of the mitigating supportive moves more than males did. It is likely due to the gender differences: female participants appear to be more sensitive than males in saving addressee's face.

\section{Conclusion}

By Analyzing four strategies, the participants used query preparatory as first strategy in their respondents. This strategy is within conventional indirectness of requesting head act strategy. They are completely familiar with request strategies and both groups employed indirectness with the most percentage. In apology strategies, the participants used illocutionary force indicating device (IFID) as the first strategy in their respondents. They used directness in their strategies. The finding of refusal strategies showed that the respondents mostly have preferred to use excuse/reason/explanation (IIC) as the first strategy. The second one used by them was statement of regret (IIA). These strategies are within indirectness of refusal strategies and they used these strategies more than other thirteen strategies in their respondents. Finally results of greeting strategies showed that the participants used formal expressions such as hello more than hi expressions. Verbal greetings were used by them in some formal situations and non-verbal greetings less than verbal in informal situations.

\subsection{Implication of the study}

Foreign language syllabus designers as well as teachers should make their students sensitive to communicate appropriately in target language. In order to help learners acquire communicative competence in speech acts use, they need to be given the chance to compare them in a variety of contexts. Role play may be recommended as a class room procedure to enhance linguistic and cultural appropriateness of different speech acts. In the same time, learners should be implicitly and explicitly instructed to observe the role of social distance and social power in performing speech acts. According to Olshtain and Cohen, cited in Gonda (2001), the model dialogues are a useful way to present learners with examples of the speech act in use. They could be asked to guess whether the people speaking know each other, if they are of the same age and whether the offence is a serious one or not. According to Phuong (2006), language instructors should design contextualized, task-based activities which expose learners to different types of pragmatic input and prompt learners to produce appropriate output; To successfully perform a speech act, language instructors should teach language forms and functions contextually in communicative oral activities in both formal and informal situations in order to develop the learners' sociolinguistic ability in an FL. 


\section{References:}

Austin, J. L. (1962). How to do things with words. London: Oxford University Press.

Alemi, M., \& Irandoost , R. (2012). A textbook evaluation of speech acts: The case of English result series. International Journal of Applied Linguistics \& English Literature, 1(6), 199-205. http://dx.doi.org/10.7575/ijalel.v.1n.6p.199

Alfattah, M. H. A. (2010). Apology strategies of Yemeni EFL university students. Modern Journal of Applied Linguistics, 2(3), 235.

Al-Momani, H. S. (2009). Caught between two cultures: the realization of requests by Jordanian EFL learners. Unpublished master's thesis. Indiana University of Pennsylvania.

Bachman, L. F. (1990). Fundamental considerations in language testing. Oxford: Oxford University Press.

Balci, B. (2009). A comparative study on the performance of requests and apologies by Turkish and American teenagers: a pragmatic competence point of view. Unpublished master's thesis, University of Cukurova, Adana, Turkey.

Beebe, L. M., Takahashi, T., \& Uliss-Weltz, R.(1990). Pragmatic transfer in ESL refusals. In R. C. Scarcella, E. S. Andersen, \& S. D. Krashen (Eds.), Developing communicative competence in second language (pp. 55-73). New York: Newbury House.

Blum-Kulka, S., \& Olshtain, E. (1984). Requests and apologies: A cross-cultural study of speech act realization patterns (CCSARP). Applied Linguistics, 5(3), 196-214. http://dx.doi.org/10.1093/applin/5.3.196

Blum-Kulka, S., House, J., Kasper, G. (1989). Cross-cultural pragmatics: Requests and apologies. Norwood, NJ.: Ablex Publication.

Brown, P., \& Levinson, S. (1987). Politeness: Some universals in language usage. New York: Cambridge University Press.

Dirven, R., \& Verspoor, M. (2004). Cognitive exploration of language and linguistics. Amsterdam: J. Benjamins Publication Company. http://dx.doi.org/10.1075/clip.1

Ellis, R. (1994). The studies of second language acquisition. Oxford: Oxford University Press.

Goffman, E. (1967). Interaction ritual: Essays on face-to-face behavior. New York: Anchor Books.

Gonda, T. (2001). The speech act of apology: apology behaviour of British English and advanced Greek speakers of English. Unpublished master's thesis, University of Essex.

Istifçi, I. (2009). The use of apologies by EFL learners. English Language Teaching, 2(3), 15-25.

Jalilifar, A. (2009). Request strategies: Cross-sectional study of Iranian EFL learners and Australian native speakers. English Language Teaching, 2(1), 46-61.

Jibreen, M. K. (2010). The speech act of greeting: A theoretical reading. Journal of Kerbala University, 8(1), 1-25.

Kaburise, P. (2011). Speech act theory and communication: A Univen study. Newcastle: Cambridge Scholars.

Moore, A. (2001).Pragmatics and speech acts. Retrieved from http://www.shunsley.eril.net/armoore

Phuong, N. T. M. (2006). Cross-cultural pragmatics: refusals of requests by Australian native speakers of English and Vietnamese learners of English. Unpublished masteral thesis University Of Queens, New York City, USA.

Reiter, R. (2000). Linguistic politeness in Britain and Uruguay; A contrastive study of requests and apologies. Amsterdam, the Netherlands: John Benjamins Publishing Company. http://dx.doi.org/10.1075/pbns.83

Searle, J. (1969). Speech acts. Cambridge: Cambridge University Press. http://dx.doi.org/10.1017/CBO9781139173438

Searle, J. R. (1976). A classification of illocutionary acts. Language in Society, 5, 1-23. http://dx.doi.org/10.1017/S0047404500006837

Stapleton, L. E. (2004).Variations in the performance of speech acts in Peninsular Spanish: Apologies and requests. Unpublished master's thesis. University of Mississippi.

Umar, A. M. A. (2004). Request strategies as used by advanced Arab. English as a Foreign Language. Umm Al-Qura University Journal of Educational \& Social Sciences \& Humanities, 16(1), 41-87.

Yule, G. (1996). Pragmatics. Oxford: Oxford University Press. 


\section{Appendix A}

\section{Multiple Discourse Completion Test}

Participants discourse completion test (MDCT)

Power: High (H), Equal (E)

Variables: Social distance: Strangers (S), Intimate (I)

Gender: Same (S), Opposite (O)

Dear Respondent,

The researcher in conducting a study entitled A study of Iranian English language teachers' familiarity with language functions in request, refusal, apology, Greeting. You are kindly requested to answer the items of this questionnaire carefully, realistically, honestly, and accurately. Rest assured that the information obtained in the course of this study will be kept confidential and used only for the purposes of academic research.

Thank you

\section{Part (1): please choose the best option.}

\section{Apology Strategies}

\section{Situation 1}

Suppose you are late for an important class and the professor very punctual and principled. How would you express your apology in this situation? The Teacher: This is the third time you're late for this class. Next time I won't let you in. You....

a. I understand. I won't be late again.

b. Sorry but the important thing is that I attend, right?

c. Things happen in life, sorry.

\section{Situation 2}

You have been asked to hand in your project, and the time is due. However, you have not prepared it, and you want to make an apology for that. How would you express your apology in this situation? The Teacher: I told you that there won't be an extension. Why didn't you prepare your term project?

You.

a. Sorry but I had too much other homework from my other projects to finish this one on time.

b. Well, I had some unexpected problems, so you should make an exception for me. c. That's true. I'm sorry. I had some unexpected obstacles, but I understand that this is the policy.

\section{Situation 3}

You are almost asleep in the class while the teacher is teaching. The teacher gets very angry when he sees you sleeping in the class. How do you express your apology? The Teacher: Did you sleep well last night? You.....
a. I'm sorry; I will try and not let it happen again.
b. I'm sorry, but I didn't sleep a wink last night.
c. Pardon me. I couldn't help it.

\section{Situation 4}

Your teacher is giving a lecture on an important topic. You have a related question to that part of his lecture. How do you interrupt your teacher? The Teacher: ...constructivist views are very important for..... (Interruption) You......
a. I don't understand what you are talking about.
b. Sorry but I really don't understand what are you saying!
c. I'm sorry to ask but could you explain a little more? 


\section{Situation 5}

Your cell phone suddenly starts ringing loudly amid a very serious discussion in the class. How would you apologize to the teacher? The Teacher to the class: It is very important to respect each other's' (the phone rings) views. You.
a. I'm sorry! This is an important call. I'll just step out for a moment.
b. (Immediately silencing the phone, which should have been silenced or turned off before the class meeting, and speaking in a very low volume so as not to increase the interruption) - I'm sorry.
c. Oh, no! I meant to turn my phone off at the beginning of the class!

\section{Request}

\section{Situation 1}

Suppose you have not understood what the teacher has just explained about "simple past tense". How do you ask for explanations about the structure of this tense?
a. Should I ask you a question?
b. How can I ask you a question?
c. Excuse me sir, may I ask you a question?

\section{Situation 2}

Suppose you have a listening class and you cannot hear what is played on T.V. How would you ask your teacher to turn it up?
a. I'm sorry, but I cannot hear.
b. I'll ask you to turn it up.
c. What? Turn it up please.

\section{Situation 3}

Suppose the teacher is writing with a red marker on the board and the color really disturbs your eyes. How would you request the teacher to use a different color?

a. Why are you writing with red! It's a pain in the neck.

b. I think you must use another color or I won't see anything on the board.

c. Excuse me; I can't read that color of pen, do you think that you could use another color when writing on the board?

\section{Situation 4}

Suppose you have been absent the previous session, and you have not understood a specific part on your own. How would you ask your teacher to give a brief explanation about that part?
a. Could you tell me what I missed last class?
b. Could you please review the grammar very quickly...
c. I don't understand the material from the previous class meeting.

\section{Situation 5}

The teacher has announced the date of midterm exam but you have another exam on that same day. How would you ask your teacher to change the date of the exam?
a. You need to change the date of the exam. We already have an exam on that day
b. Could you please possibly take the exam some other day?
c. Couldn't we just not have the exam? We have one exam already on that day. 
Valipour, S. \& Jadidi, S.

\section{Refusals}

\section{Situation 1}

One friend of your brother's asks to borrow your car to take his/her family members outing. You would really prefer not to lend your car to anyone. What would you say if you want to refuse?

a. No, I can't.

b. Sorry, I'm afraid I can't.

c. What about you asking him to borrow it to you?

\section{Situation2}

You are a professor. One day one of your students comes to you to borrow a book. You do not really know him, and you worry that he cannot return the book. What would you say if you want to refuse?
a. No, I can't.
b. Sorry, I'm afraid I can't.
c. Pity! I've lent it to another student.

\section{Situation 3}

Your close friend asks you to help decorate his house. You have an important exam coming up. What would you say if you want to refuse?

a. Sorry, I'm afraid I couldn't.

b. I would be happy to help you If I hadn't too hard exam tomorrow.

c. Sorry, I'm really busy these days preparing for my exam.

\section{Situation 4}

Your teacher asks you to stay after school to help clean up his office. You really have many other things that you need to do. What would you say if you want to refuse?

a. Sorry, I'm afraid I can't.

b. I wish I could.

c. Miss Li, I'm afraid I can't. I have something important to do during that time.

\section{Situation5}

One day, your friend's teacher (he does not know who you are) is playing Basketball on the playground and catches sight of you walking by. He invites you to join him. What would you say if you want to refuse?

a. No, I've no interest.

b. Sorry, I'm afraid I couldn't.

c. I'd love to but I am poor at playing at basketball.

\section{Greeting}

\section{Situation 1}

Suppose you are a student. You want to speak with your professor. How to talk with your professor to open the conversation?

a. hello professor

b. Excuse me professor, Can I take your time?

c. Good day professor

\section{Situation2}

Suppose you want to talk with your partner. How to talk with your partner?

a. Hello, Are you fine? 
b. Good day, Are you ok?

c. How do you do?

\section{Situation 3}

Oscar sees an acquaintance, Bill, from a neighboring apartment as he is leaving his apartment building for work. If Oscar does not have time to stop and chat, what would be his most likely choice of greetings as he passes the neighbor?

a. Hey, Bill! How are you doing? What's going on in your life? We should catch up!

b. Morning', Bill, how's it going?

c. Good morning, Bill! What's on the agenda for the day?

\section{Situation 4}

You want to talk with a foreigner person who has opposite gender. How to talk with him after familiarity with him?

a. Hello, it's very nice to see you.

b. Nice to see you

c. Good day. It's nice to see you.

\section{Situation 5}

Suppose you want to talk for the first time with an older person who is foreigner. How to talk with him?
a. Hello Mr. /Mrs. Don't bother
b. sorry, I want to say something
c. Hello, excuse me. Can I take your time?

\section{Appendix B}

\section{Written Discourse completion test}

Part (2): Please read the following descriptions of situations and write what you will say in each situation. If your answer in Part B is the same as part A, please mark only the same. If it is not, write differently.

\section{Request strategies}

1. A-(ESS): You have to prepare homework. You need $\underline{\mathbf{a} \text { book }}$ and you have seen that particular book in the office of a professor whom you don't know him. You want to borrow his book for a few days. How will you request it?....

B- (ESO): how will you request if the professor is opposite gender?

2. A- (EIS): In institute you are reading a passage and face with a new word. You forgot your dictionary. You want to ask from a teacher who is your intimate friend and sitting next to you. You want to borrow $\underline{\text { his }}$ dictionary. What will you say?.

B-(EIO): How will you request if the teacher is opposite gender?

3. (HIS): You are a student you have a lot of homework and you must finish it by tomorrow. There are some Math problems that you can't solve by yourself. Your elder brother is a professor at college. You want him to help you with your Math homework. How will you request him to help you?.

B-(HIO): What will you say if the professor is opposite gender?

4. (HSS): you are a student in the university. You have a class with the professor whom don't you know. 
Valipour, S. \& Jadidi, S.

You want to request to leave the class because you have a problem. $\underline{\mathbf{H e}}$ is a much disciplined professor. You should go and solve it. What will you say?

B-(HSO): How will you request if the professor is opposite gender?

5. (LSS): You are a teacher in the class. You are teaching in English class. One of the male students is very busy. He speaks a loud in the class and doesn't listen to you. You want to request $\underline{\mathbf{h i m}}$ to be silent. How will you request?

B-(LSO): how will you request if the student is opposite gender?

6. A-(LIS): You are an English teacher. You have forgotten one of your books. You want to borrow one of your student's books who are very close with you. He is your friend's son. How will you request his book?.

B- (LIO): What will you say if the student is opposite gender?

\section{Refusal strategies}

1. A-(ESS): You are an English teacher in institute. One of English teacher whom you don't know has invited you to his home. You have a problem and must write some questions for exam. You want to refuse his request by saying:

B-(ESO): How will you refuse if the teacher is opposite gender?

2. A- (EIS): Imagine that you are a student at Azad University of Maraghe. While you are planning your next semester's courses, you consulted one of your best classmates who are in your department. $\underline{\mathrm{He}}$ is your intimate friend and sits next to you. Classmate: Well, that course is OK, but if you take this one first, it would be better. You refuse his request by saying:.....

B-(EIO): You refuse his request if the classmate is opposite gender?

3. (HIS): You are one of the staffs in a multinational company. Your new coming boss, who is your intimate friend, asks if he can borrow your car for a few days. He says "Could you please lend me your car for one week? My car has broken down, and I know that you've two cars now". You refuse his request by saying:

B- (HIO): What will you say if the boss is opposite gender?

4. A-(HSS): Imagine that you are as a student studying at a university in Iran. In a meeting with a professor whom you don't know to plan the next semester's courses, the professor suggested a course to be taken. Professor: it seems to me that you need to take a course in research methods. So, I would strongly suggest that you take this course before you start writing your thesis. You refuse his Request by saying:

B- (HSO): how will you request if the professor is opposite gender?

5. A-(LSS): you are a teacher in high school. One of the students who are in other class and you are not his

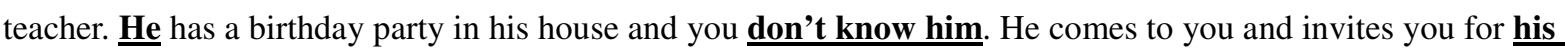
party. You refuse his invitation by saying:

B-(LSO): How will you refuse if the student is opposite gender? 
Iranian English language teachers' familiarity with language functions in request, apology, refusal, and greeting

6. A-(LIS): You are teaching in the English class. You face with extra time. Suddenly one of your students who are your best friend's son wants to leave the class. You refuse his request by saying:

B-(LIO): How will you refuse if that person has opposite gender?

\section{Greeting strategies}

1. A-(ESS): As a teacher you are teaching English in one of schools of your city. You are passing from the valley. Suddenly one of teachers from other school you don't know her meets you. You are going to greet her. You will say:.

B-(ESO): how will you greet if the teacher is opposite gender?

2. (EIS): You teach in an English institute. One of your intimate best friends comes to you. She greets you and says: How are you? You greet her by saying:

B-(EIO): how will you greet if that teacher is opposite gender:

3. A-(HIS): You are passing the street. Suddenly you see one of your best professors whom you know and $\underline{\text { is }}$

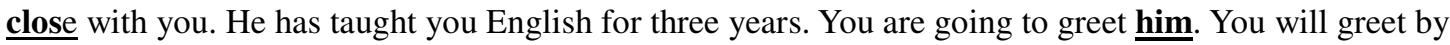
saying:

B-(HIO): how will you greet if the professor is opposite gender:

4. A- (HSS): You are a student at the college. You go to your professor because you want to ask questions. Another professor is standing your professor whom you don't know. He greets you. You will greet him by saying:

B-(HSO): How will you greet if that professor is opposite gender?

5. A-(LSS): You are an English teacher. You have English classes on Tuesdays. One of the students whom you don't know him says hello and greets. You will greet by saying:

B-(LSO): how will you greet if the student is opposite gender:

6. A- (LIS): You are an English teacher. You have invited to one party. Suddenly you see one of your $\underline{\text { students }}$ in the party who is very close with you. You are going to greet him by saying:

B-(LIO): How will you greet if the student is opposite gender?

\section{Apology strategies}

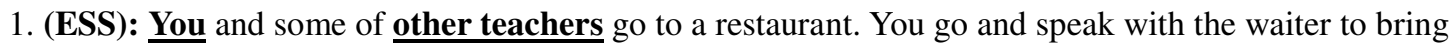
extra food. Suddenly you are carrying your meal to your table. When you are walking between tables, you stumble and your soup spills over one of teacher's coat whom you don't know him well. He gets unhappy. You apologize by saying:

B-(ESO): how will you apologize if the teacher is opposite gender? 
Valipour, S. \& Jadidi, S.

2. A-(EIS): Backing out of a parking place, you run into the side of another car. It was clearly your fault. You dent the side door slightly. It was your friend's car. $\underline{\text { He gets out and comes over to you angrily. He is an old }}$ teacher in your school, but you are young. Driver: "Can't you look where you're going? See what you've done!" You will apologize by saying: You:

B-(EIO):How will you say if the teacher is opposite gender?

3. A-(HIS): You are a student at collage. You want to make an appointment with your professor at his office. But you were 15 minutes late because the closest parking place was full. You knock on the door, go in, and apologize by saying?

B-(HIO): How will you apologize if the professor is opposite gender?

4. A: (HSS): In a crowded elevator, you step on somebody's (adult-your age) foot. $\underline{\text { He }}$ is an old man and you don't know him. He gets angry and you are going to apologize him by saying:

You:

B-(HSO): How will you apologize if that person is opposite gender?

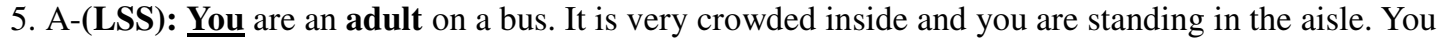
accidentally step on the foot of the boy who is standing next to you. You apologize by saying:

B-(LSO): how will you apologize if that person is opposite gender?

6. A-(LIS): You are a teacher. You forgot to bring your book and borrow your student's book for a few days. He is very close with you. You forget to return his book. He comes to you and requests his book to study for exam. You will apologize by saying:

B-(LIO): How will you apologize if the student is opposite gender? 